\title{
Case-control study of occupation and cancer of the prostate in New Zealand
}

\author{
NEIL E PEARCE, 12 RAEWYN A SHEPPARD, ${ }^{1}$ AND JAMES FRASER ${ }^{3}$ \\ From the Department of Community Health, ${ }^{\prime}$ Wellington Clinical School of Medicine, Wellington Hospital, \\ Wellington, New Zealand; Department of Epidemiology, ${ }^{2}$ School of Public Health, University of North Carolina, \\ Chapel Hill, NC 27514, USA; and National Health Statistics Centre, Wellington, New Zealand
}

SUMmary A New Zealand Cancer Registry based case-control study involved 617 male patients with prostate cancer registered during 1979 and aged 20 years or more at the time of registration. Controls were also males chosen from the Cancer Registry with two controls per case, matched on age and year of registration. There was an elevated risk in the upper social class groupings. The data did not support the findings, from other countries, of elevated risks in agricultural workers (odds ratio $=1 \cdot 08,90 \%$ confidence limits $0 \cdot 86-1 \cdot 36)$. The only occupational groups showing elevated risks were sales and service workers (odds ratio $=1 \cdot 29,90 \%$ confidence limits $0.99-1 \cdot 69$ ) and teachers (odds ratio $=2 \cdot 44,90 \%$ confidence limits $1 \cdot 05-5 \cdot 70$ ). The New Zealand data do not in general suggest that occupational factors-or lifestyle factors associated with occupation-are of major direct importance in the aetiology of prostate cancer.

The major causes of prostate cancer are unknown, and relatively few epidemiological studies have been carried out to date. ${ }^{1}$ The best documented occupational hazard is exposure to oxides of cadmium, but the findings are inconsistent. ${ }^{2}$ Few other occupational risk factors have been identified. Henry $e t \mathrm{al}^{3}$ examined mortality in England and Wales during the period 1921-8 and found excess risks for agricultural occupations, french-polishers, engine drivers, firemen, and cleaners. The British RegistrarGeneral's studies ${ }^{4}$ have found elevated risks for employers, foremen, farmers, and members of the armed forces; and Ernster's study of prostate cancer mortality in two California counties found excess risks for farmers, compositors, shipfitters and jobs involving chemical exposure. ${ }^{5}$ The United States Third National Cancer Survey ${ }^{6}$ found that prostate cancer was associated with ministers, farmers, plumbers, rubber workers, coal miners, and retailers. The association with rubber workers has also been found in specific studies of rubber industry workers. ${ }^{7}$ Other studies have found associations with chemists; ${ }^{8}$ policemen, farmers, and labourers; ${ }^{9}$ and farmers. ${ }^{10}$

Finally, a Los Angeles study found the incidence of prostatic cancer to be higher in the upper social class groupings. ${ }^{11}$ This pattern was also observed in England and Wales at the beginning of this century but the gradient has now declined and the most recent studies in England and Wales, ${ }^{4}$ Italy, ${ }^{12}$ and New
Zealand ${ }^{13}$ have found no significant social class gradient.

Hence the most consistent findings regarding occupations at high risk of prostate cancer involve cadmium workers, rubber workers, and farmers. The latter association is of particular interest since the agricultural industry is of major importance in New Zealand, and a series of case-control studies has found elevated risks for farmers for several other cancer sites. ${ }^{1415}$ Elevated risks were also found for meat workers who may be exposed to common risk factors. These studies involved the use of other cancer patients as controls, and an examination of the control patient data suggested that farmers and meat workers may also be at risk of prostate cancer. Accordingly, two further case-control studies were initiated and we here report the findings for the prostate cancer study.

\section{Methods}

The case group comprised all male patients registered with the New Zealand Cancer Registry during 1979 who were classified under code 185 of the International Classification of Diseases (ICD) ${ }^{16}$ and who were aged 20 years or more at the time of registration. The control group was selected from other cancer patients appearing on the Cancer Registry. The main advantage of this approach lies in the minimisation of information bias, since cases and 
controls are drawn from the same registry. ${ }^{17}$ Two controls were chosen for each case who were within two years of age, were registered in the same year, and were not registered as a case of testis cancer (ICD 186), this latter group being included as a case group in a concurrent study.

New Zealand cancer registrations and death registrations include current or most recent occupation coded according to the New Zealand Standard Classification of Occupations. ${ }^{18}$ This information was used to compare the occupational distributions of the case group and the control group. The social class distributions were compared using the British Registrar-General's classification, ${ }^{19}$ which has shown a moderate gradient for cancer mortality in a recent New Zealand study. ${ }^{20}$

Odds ratios were computed using the MantelHaenszel method, ${ }^{21}$ and Miettinen's approximate method was used to calculate confidence limits. ${ }^{22}$ Tests for trend with social class were performed using the Mantel-Haenszel extension test. ${ }^{23}$ The matched and unmatched (crude) analyses gave very similar results, and adjustment for social class did not affect the occupational comparisons. Hence the crude analysis was used throughout.

\section{Results}

A total of 617 cases of prostate cancer were included in the study and 2-1 matching yielded 1234 controls. Table 1 demonstrates that there was a tendency for the cases to include more men with occupations belonging to the upper social classes $(p<0.01)$.

The occupational distributions of the cases and controls are presented in table 2 . The largest excess risk was for sales and service workers, and was largely due to excesses for sales and service managers, and

Table 1 Odds ratios for prostate cancer by Registrar General's social class

\begin{tabular}{|c|c|c|c|c|}
\hline $\begin{array}{l}\text { British } \\
\text { Registrar-General's } \\
\text { social class }\end{array}$ & Cases & Controls & $\begin{array}{l}\text { Odds } \\
\text { ratio }\end{array}$ & $\begin{array}{l}90 \% \\
\text { Confidence } \\
\text { limits }\end{array}$ \\
\hline I & 25 & 55 & 1.01 & $0.67-1.52$ \\
\hline II & 177 & 315 & 1.41 & $1 \cdot 16-1 \cdot 71$ \\
\hline IIIN & 50 & 106 & 1.06 & $0.78-1.42$ \\
\hline IIIM & 127 & 311 & 0.87 & $0.71-1.07$ \\
\hline IV & 46 & 137 & 0.72 & $0.53-0.97$ \\
\hline $\mathbf{V}$ & 32 & 92 & 0.76 & $0.53-1.07$ \\
\hline $\begin{array}{l}\text { Unknown/ } \\
\text { unemployed/ } \\
\text { student/army* }\end{array}$ & 160 & 218 & - & - \\
\hline Total & 617 & 1234 & - & - \\
\hline
\end{tabular}

*Excluded from analysis
Table 2 Odds ratios for prostate cancer by major occupational categories

\begin{tabular}{|c|c|c|c|c|}
\hline Occupational group & Cases & Controls & $\begin{array}{l}\text { Odds } \\
\text { ratio }\end{array}$ & $\begin{array}{l}90 \% \\
\text { limits }\end{array}$ \\
\hline Professional/technical & 57 & 108 & $1 \cdot 20$ & $0.90-1.60$ \\
\hline $\begin{array}{l}\text { Administrative/ } \\
\text { managerial }\end{array}$ & 29 & 51 & 1.29 & $0.87-1.91$ \\
\hline Clerical & 32 & 91 & 0.77 & $0.54-1.09$ \\
\hline $\begin{array}{l}\text { Sales/service } \\
\text { Managers (sales and service) } \\
\text { Working proprietors (sales) } \\
\text { Commercial travellers } \\
\text { Insurance, real estate } \\
\text { Salespersons, shop workers } \\
\text { Working proprietors (service) } \\
\text { Cooks, waiters, bartenders } \\
\text { Caretakers, cleaners } \\
\text { Protective service workers } \\
\text { Sales and service NEC }\end{array}$ & $\begin{array}{r}70 \\
6 \\
15 \\
12 \\
4 \\
10 \\
2 \\
1 \\
5 \\
5 \\
10\end{array}$ & $\begin{array}{r}125 \\
4 \\
22 \\
10 \\
10 \\
18 \\
8 \\
10 \\
15 \\
18 \\
10\end{array}$ & $\begin{array}{l}1 \cdot 29 \\
3 \cdot 38 \\
1 \cdot 54 \\
2 \cdot 72 \\
0.89 \\
1 \cdot 25 \\
0.56 \\
0.22 \\
0.74 \\
0.62 \\
2 \cdot 26\end{array}$ & $\begin{array}{l}0.99-1.69 \\
1 \cdot 24-9.22 \\
0.88-2.68 \\
1.38-5.39 \\
0.34-2.37 \\
0.65-2.40 \\
0.15-2.01 \\
0.05-1.07 \\
0.32-1.74 \\
0.27-1.41 \\
1 \cdot 10-4.65\end{array}$ \\
\hline $\begin{array}{l}\text { Agriculture/forestry/fishing } \\
\text { Farmers/farm managers } \\
\text { Agricultural workers } \\
\text { Forestry/fishing }\end{array}$ & $\begin{array}{r}94 \\
79 \\
13 \\
2\end{array}$ & $\begin{array}{r}197 \\
158 \\
30 \\
9\end{array}$ & $\begin{array}{l}1.08 \\
1 \cdot 14 \\
0.97 \\
0.49\end{array}$ & $\begin{array}{l}0.86-1.36 \\
0.90-1.46 \\
0.56-1.68 \\
0.14-1.75\end{array}$ \\
\hline $\begin{array}{l}\text { Labourers/production/ } \\
\text { transport }\end{array}$ & 177 & 452 & 0.79 & $0.66-0.96$ \\
\hline $\begin{array}{l}\text { Unknown/unemployed/ } \\
\text { student* }\end{array}$ & 158 & 210 & - & - \\
\hline Total & 617 & 1234 & - & - \\
\hline
\end{tabular}

*Excluded from analysis

commercial travellers. There was only a very modest excess risk for agricultural occupations, and table 2 suggests that the relative risk for this category is unlikely to be larger than 1.4 . The very modest excess risk was confined to farmers and farm managers.

Other occupational groups were also examined. The only group with an elevated odds ratio was teachers (odds ratio $=2 \cdot 44,90 \%$ limits $=1 \cdot 05-5 \cdot 70$ ). There was no excess risk for meat workers, and none of the cases or controls was identified as a rubber worker.

\section{Discussion}

The epidemiology of prostate cancer is of increasing interest since the aetiology is largely unknown, and age standardised incidence and mortality from prostate cancer have increased markedly in New Zealand during the last 30 years (unpublished data). The increase has been consistent across age groups, and the annual increase has averaged $2.3 \%$ for incidence and $0.4 \%$ for mortality. An increase in incidence in the older age groups has also occurred in England and Wales and is likely to be due, in part, to diagnostic factors. ${ }^{24}$ The increase in mortality has not been observed in England and Wales although mortality increased in the older age groups earlier this century before levelling off.

This study has provided further evidence of a weak social class gradient in prostate cancer risk. The 
occupational findings are largely negative but still, of course, merit being placed on record. There was no excess risk for farmers or for workers processing agricultural products, and the data suggest that the relative risk for farmers is most unlikely to be greater than 1.4. This is puzzling in the light of the positive findings from other studies, although these have not been completely consistent and have not revealed any compelling associations with specific agricultural agents. ${ }^{10}$ A New Zealand mortality study did find an excess risk for farmers, but the number of deaths involved was small. ${ }^{13}$

The positive findings for sales and service workers and teachers are also inconsistent with findings in previous work and should be regarded with considerable reservation due to the multiple comparisons involved and the lack of any obvious common risk factors.

In general, it appears that occupational factors are not of major importance in the aetiology of prostate cancer, although a few specific associations may warrant further scrutiny. Further study of nonoccupational risk factors would clearly be valuable, given that prostate cancer is an increasingly important source of mortality in New Zealand men.

This investigation was completed during the tenure by NEP of an Overseas Research Fellowship of the Medical Research Council of New Zealand. It was supported by grants from the Medical Research Council of New Zealand and the New Zealand War Pensions Medical Research Trust. We wish to thank Keir Howard and Barbara Lilley for administrative and technical help, the staff of the New Zealand Health Statistics Centre and the New Zealand Cancer Registry for their excellent co-operation, and Betsy Seagroves for manuscript preparation. J Fraser wishes to thank the Director General of Health for permission to publish these data.

\section{References}

${ }^{1}$ Greenwald P. Prostate. In: Schottenfeld D and Fraumeni JF (eds). Cancer epidemiology and prevention. Philadelphia: WB Saunders, 1982.

2 Armstrong BG, Kazantzis G. Prostatic cancer and chronic respiratory and renal disease in British cadmium workers: a case control study. Br J Ind Med 1985; 42: 540-5.

${ }^{3}$ Henry SA, Kennaway NM, Kennaway EL. The incidence of cancer of the bladder and prostate in certain occupations. J Hyg (Camb) 1931; 30: 125-37.
${ }^{4}$ Logan WPD. Cancer mortality by occupation and social class 1851-1971. London: HMSO, 1982.

5 Ernster VL, Selvin S, Brown SM, et al. Occupation and prostatic cancer: a review and retrospective analysis based on death certificates in two Californian counties. $J$ Occup Med 1979; 21: 175-83.

${ }^{6}$ Williams RR, Stegens NL, Goldsmith JR. Associations of cancer site and type with occupation and industry from the Third National Cancer Survey interview. J Natl Cancer Inst 1977; 59: 1147-85.

${ }^{7}$ Goldsmith DF, Smith AH, McMichael AJ. A case-control study of prostate cancer within a cohort of rubber and tire workers. J Occ Med 1980; 22: 533-41.

${ }^{8}$ Olin RG. The hazards of a chemical laboratory environment. A study of the mortality in two cohorts of Swedish chemists. Ann Indust Hyg Assn J 1978; 39: $557-62$.

${ }^{9}$ MacDonald E. Natural histcry of prostate cancer. Proceedings of the Third National Cancer Conference. Philadelphia: Lippincott, 1956.

${ }^{10}$ Blair A, Malker H, Cantor KP, et al. Cancer among farmers: a review. Scand J Work Environ Health 1985; 11 : 397-407.

${ }^{11}$ Ross RK, McCurtis JW, Henderson BE, Menck HR, Mack TM, Martin SP. Descriptive epidemiology of testicular and prostatic cancer in Los Angeles. $\mathrm{Br} J$ Cancer 1979; 39: 284-92.

12 Talamini R, LaVecchia C, Decarli A, Negri E, Franceschi S. Nutrition, social factors and prostatic cancer in a Northern Italian population. $B r J$ Cancer 1986; 53: 817-21.

${ }^{13}$ Pearce NE, Howard JK. Occupation, social class and male cancer mortality in New Zealand, 1974-78. Int J Epidemiol, 1986; 15: 456-62.

14 Pearce NE, Smith AH, Fisher DO. Malignant lymphoma and multiple myeloma linked with agricultural occupations in a New Zealand Cancer Registry based study. Am J Epidemiol 1985; 121: 225-37.

${ }^{15}$ Pearce NE, Sheppard RA, Howard JK, Fraser J, Lilley BM. Leukemia among New Zealand agricultural workers: a Cancer Registry based study. Am J Epidemiol 1986; 124: 402-9.

16 World Health Organization. Manual of the international statistical classification of diseases, injuries and causes of death, 8th revision. Geneva: WHO, 1967.

17 Smith AH, Pearce NE. Occupational case-control studies with other cancer controls. Am J Ind Med in press (abstract).

18 Department of Statistics. New Zealand standard classification of occupations. Wellington: Department of Statistics, 1980.

${ }^{19}$ Office of Population Censuses and Surveys. Classification of occupations. London: HMSO, 1980.

20 Pearce NE, Davis PB, Smith AH, Foster FH. Social class, ethnic group and male mortality in New Zealand 1974 78. J Epidemiol Comm Health 1985; 39: 9-14.

${ }^{21}$ Mantel N, Haenszel W. Statistical aspects of the analysis of data from retrospective studies of disease. $J$ Natl Cancer Inst 1959; 22: 719-48.

${ }^{22}$ Miettinen O. Estimability and estimation in case-referent studies. Am J Epidemiol 1976; 103: 226-35.

23 Mantel N. Chi-square tests with one degree of freedom: Extensions of the Mantel-Haenszel procedure. $J \mathrm{Am}$ Statist Assoc 1963; 58: 690-700.

${ }^{24}$ Alderson MR. Epidemiology. In: Duncan W (ed). Prostate cancer. Recent Results Cancer Res 1981; 78: 1-19. 